УДК 621.744

Mikhailo Medvediev/Dr. Sci. (Eng.)/, Yaroslav Frolov/Dr. Sci. (Eng.)/, Vitalii Andreiev/Cand. Sci. (Tech.)/, Oleksandr Bobukh /Cand. Sci. (Tech.)/, Anastasiya Vovk
National metallurgical academy of Ukraine,

Dnipro, Ukraine

\title{
EXPERIMENTAL ESTIMATION OF MAXIMAL DUCTILITY AND FLOW CURVES OF TITANIUM ALLOYS WITH HOT-TORSION TESTS
}

М.I. Медведєв /д.т.н./,

Я.В. Фролов /д.т.н., проф./,

В.В. Андреєв /к.т.н./,

О.С. Бобух /к.т.н./,

А.С. Вовк /аспірант/
Національна металургійна академія України, м. Дніпро, Україна

\section{ЕКСПЕРИМЕНТАЛЬНЕ ДОСЛІДЖЕННЯ МАКСИМАЛЬНОЇ ПЛАСТИЧНОСТІ ТА КРИВИХ ЗМЦНЕННЯ ТИТАНОВИХ СПЛАВІВ ЗА ДОПОМОГОЮ ВИПРОБУВАНЬ НА ГАРЯЧЕ КРУТІННЯ}

Purpose. The purpose of this work is to clarify the temperature-deformation modes of pressing pipes of titanium alloys (VT1-0, PT-7M, VT-14,VT-15, TS-5 and TS-6) and to determine the regression coefficients of the Hansel-Spittel equation by investigating plasticity and the deformation resistance during hot rotation of the specimens.

Methodology. Studies on torsion were performed on a torsion test machine with a horizontal electronic force meter, with a maximum torque of $100 \mathrm{H} \times \mathrm{m}$, temperature. The maximum temperature of the test specimens was $1250{ }^{\circ} \mathrm{C}$. Active capture of the test machine has a smooth rotation control from 5 to $200 \mathrm{rpm}$. Applying specimens with different aspect ratio to the length of the workpiece obtained a range of change of strain rates from 0.25 to $20 \mathrm{c}^{-1}$.

Findings. The main results of the study should be considered experimentally determined curves of the torque dependence on the angle of rotation of the sample to change the resistance of deformation of the metal, which allowed to clarify the temperature interval of maximum ductility during pressure treatment for alloys VT1-0, PT-7M, VT-14, VT-15, TS-5 and TS-6. Based on the data obtained on the deformation resistance, the coefficients of the Hansel-Spittel equation, which can be used to quantify the resulting stress in numerical simulation using the finite element method, have been statistically calculated.

Originality. The data on experimentally determined regularities of influence of temperaturedeformation modes of torsion on the change of the value of deformation resistance, which is characteristic of conditions of hot pressing of pipes, have been further developed. This allows to predict the power parameters of the deformation process, as well as to select the press equipment and improve the productivity of the press line.

Practical implications. Studies on torsion have allowed to determine rational temperature-speed parameters of the process of pressing pipes from titanium alloys VT1-0, PT-7M, VT-14,VT-15, TS-5 and TS6, for capacities of Ukrainian enterprises.

Key words: titanium, deformation, torsion, torque, temperature, strain rate, strain resistance, extrusion, tube.

DOI: $10.34185 / 0543-5749.2019-5-6-114-122$

(C) Mikhailo Medvediev, Yaroslav Frolov, Vitalii Andreiev, Oleksandr Bobukh, Anastasiya Vovk, 2019 
Introduction. Manufacturing of seamless tubes due to the complex strain-stress state in deformation zone requires not trivial approaches to accounting of changes of metal properties [1, 2]. In this case prescribing of strain, temperature and speed parameters at hot tube extrusion can be based on results of hot-torsion tests [3-5]. This method using the torque, obtained at test procedures, makes it possible to get a complete picture of the metal flow developing in conditions of prevailing shear deformation. The shear strain, calculated from torque curves, is used as an indicator of transition to plastic area and consequent failure [6].

Materials and research methods. The objective of presented study is a quantitative analysis of both strain and stress coordinates of the torque at hot-torsion tests. This analysis is based of position of $\mathrm{M}_{\mathrm{Cr}}$ on the torsion test diagram (Fig. 1).

Figure 1 shows the typical diagram of hot torsion These "torque versus angle" diagrams allow to trace change of the torque as a marker of shear stress as well as the shear strain in the specimen.

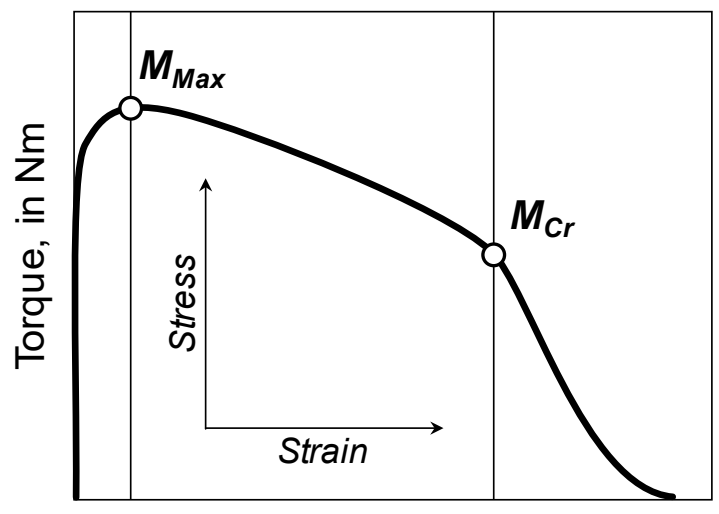

Twisting angle (rotations)

Fig. 1. Typical diagrams for torsion tests without securing the passive grip of the machine
"Torque versus angle" diagram, presented on the Fig. 2 show three major characteristic sections of change in torque:

1. First section is characterized by an increase of the torque. This quite narrow stage reflects the metal hardening before the transition to plastic flow. The maximal value of the torque $\left(M_{M a x}\right)$ means reaching of the flow stress in the specimen being tested.

2. Second section, which is characterized by a smooth almost linear decrease of the torque. Metal flows here with help of the dynamic return mechanism with cross slip or creep of dislocations [7] until reaching of the limit of ductile behavior, as evidenced the critical Moment $\left(M_{C r}\right)$.

3. In the Third section an intensive decrease of the torque can be observed. It ends with a specimen failure.

Therefore, the area of ductile behavior of metal is limited by only the second section. The coordinates of $\mathrm{M}_{\mathrm{Cr}}$ point are significantly depending on temperature and stain rate. It means that both components of that coordinate (strain and stress) should be estimated for current temperature and strain rate. We'll present and analyze the results of such estimation for described in the Table 1 alloys consistently: first strain and then - stress.

The hot-torsion tests were performed on a testing machine SMEG-10T (torsion machine of the horizontal type with a maximum torque $100 \mathrm{Nm}$, equipped with a heating chamber). The temperature of the samples during the tests was in range of $800 \ldots 1250^{\circ} \mathrm{C}$. Active grip of testing machine provides an adjustment of speed from 5 to $200 \mathrm{rpm}$. Passive grip has not been secured to make the specimen be able to change its length during the testing freely. It is intended to eliminate an occurrence of additional axial stresses.
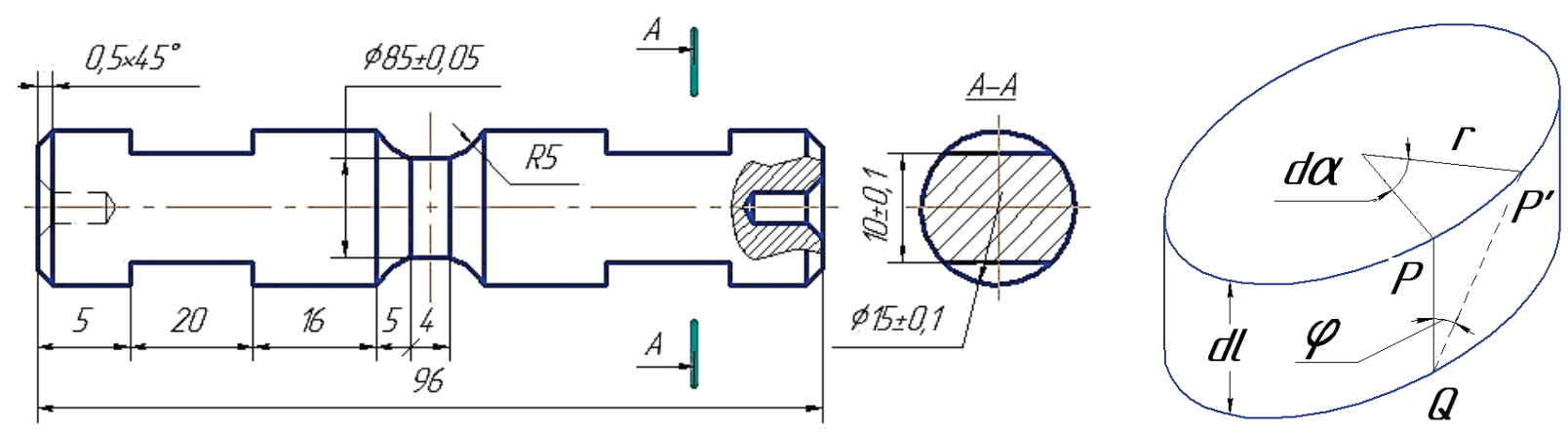

a

b

Fig. 2. General view of specimen for torsion testing (a) and scheme for determining of the torsion angle $\varphi(b)$ 
Table 1. Chemical composition of studied titanium alloys according to OCT 1.90013-81 [8]

\begin{tabular}{|l|c|c|c|c|c|c|c|c|}
\hline \multicolumn{1}{|c|}{ Alloy grade } & $\mathrm{Ti}$ & $\mathrm{Al}$ & $\mathrm{Mo}$ & $\mathrm{V}$ & $\mathrm{Zr}$ & $\mathrm{Cr}$ & $\mathrm{Sn}$ & Other \\
\hline BT1-0 (VT1-0) & 99,472 & - & - & - & - & - & - & 0,528 \\
\hline BT14 (VT14) & 89,55 & 4,9 & 3,2 & 0,9 & - & - & - & 1,45 \\
\hline BT15 (VT15) & 78,568 & 2,7 & 7,5 & - & - & 10,2 & - & 1,032 \\
\hline TC5 (TS5) & 85,67 & 5,2 & - & 2,1 & 2,7 & - & 3,3 & 1,03 \\
\hline TC6 (TS6) & 73,72 & 2,95 & 4,1 & 6,7 & 0,75 & 10,8 & - & 0,98 \\
\hline ПT7-M (PT7-M) & 94,434 & 2,1 & - & - & 2,5 & - & - & 0,966 \\
\hline
\end{tabular}

Research results. Estimation of critical strain. Although the torsional deformation is not monotonous, the degree of shear strain according to $[9,10]$ can be calculated:

$$
\Lambda_{C r}=\operatorname{tg} \varphi \text {, }
$$

where $\varphi-$ tilt angle of the artificial stress concentrator (notch) on the specimen ( $P Q$ line at fig. 2(b)).

When it is allowed what the distribution of strain along the length of the specimens is monotonous, critical shear strain (1), which leads to the failure can be represented as:

$$
\Lambda_{C r}=\frac{2 \cdot \pi \cdot r \cdot n}{l}
$$

where $r$ - specimen radius, $\mathrm{mm} ; n$ - number of rotations until reaching the $M_{C r} ; l-$ specimen length, mm.

A general view of the specimen used in the tests is shown in Figure 2.

The strain rate was determined by the following equation:

$$
\dot{\varepsilon}=\frac{\pi \cdot r \cdot N}{30 \cdot l},
$$

where $N$ - revolving speed, rpm.

Using specimens with a different ratio of radius to the length of the working part, were obtained the range of the strain rates from 6 to $25 \mathrm{~s}^{-1}$.

The results of the torsion tests of specimens made of above-mentioned alloys are performed in the form of graphical dependences of the critical shear deformation on temperature, a characteristic view of which is shown in Figure 3. Such performance allows to find temperature range for each alloy where its ductile behavior exists longer. That statement assumes that the higher $M_{c r}$, the higher strain until it is reaching.
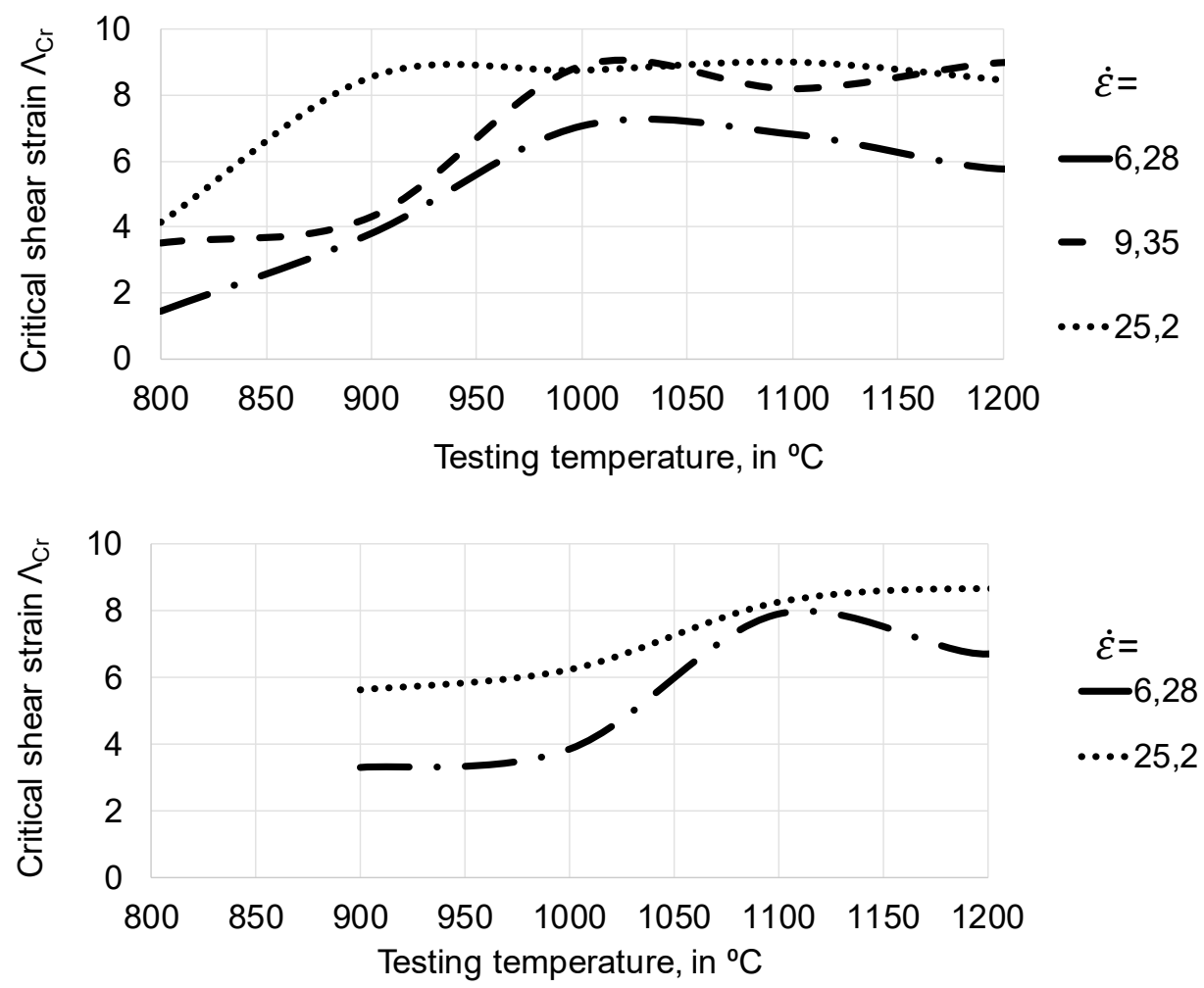

Fig. 3 a, b. Graphic dependences of the degree of shear strain on the test temperature: a - VT1-0; $\mathrm{b}-\mathrm{VT} 14$ 

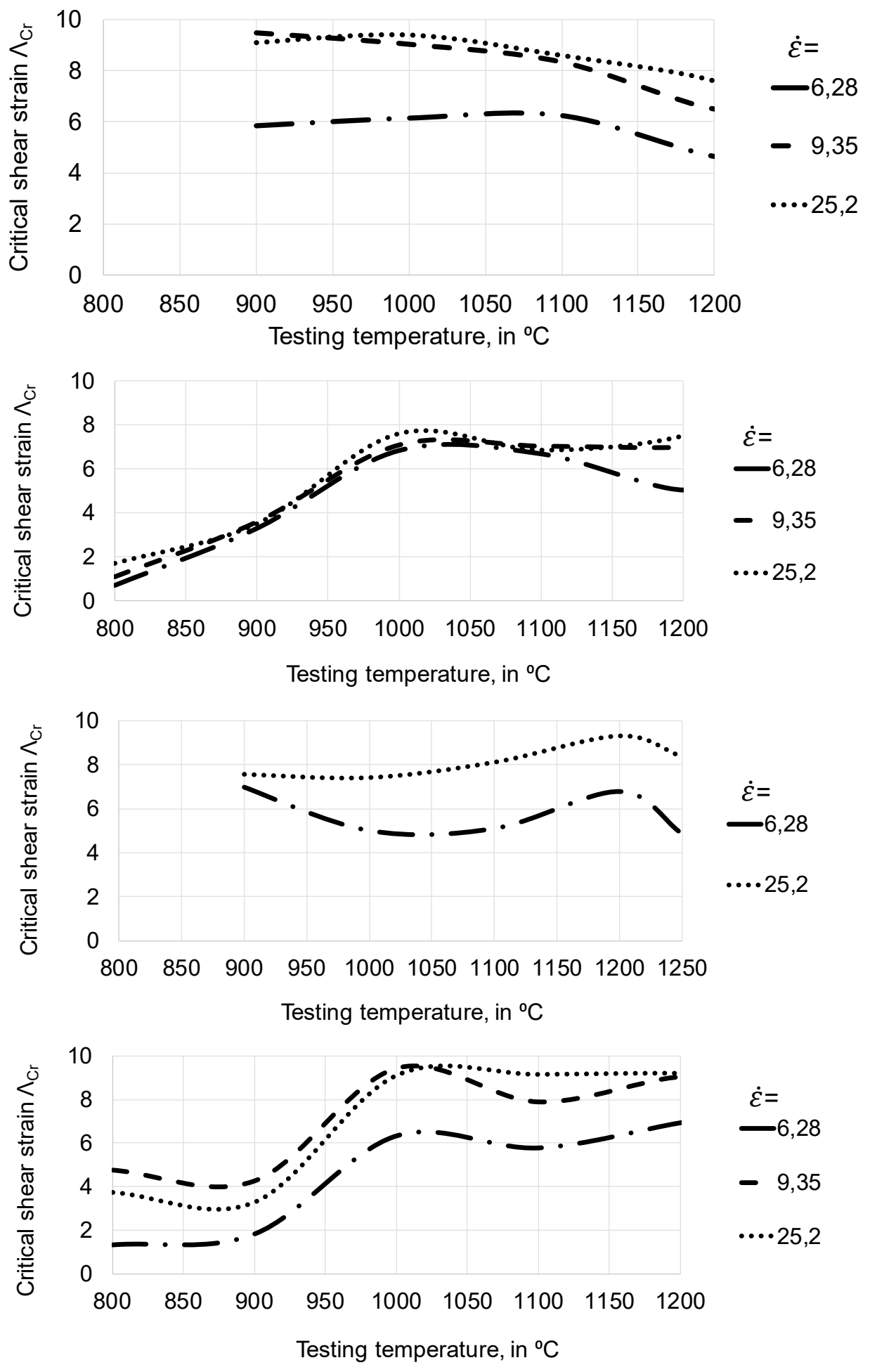

$\mathbf{e}$

f

Fig. 3 c, d, e, f. Graphic dependences of the degree of shear strain on the test temperature: c - VT15; d-TS5; e - TS6; f-PT7-M

According to the graphical dependences (Fig. 3), it is possible to determine the temperature ranges of maximal length of $M_{M a x}-M_{C r}$ line at metal forming of the studied alloys. Thus, the longest life of ductile behavior can be observed at followed temperature range:
- VT1-0 - 900 ...1000 ${ }^{\circ} \mathrm{C}$. Maximal ductility interval moves in low temperatures area at strain rate $25,2 \mathrm{~s}^{-1}$;

- VT14 - $1050 \ldots 1150{ }^{\circ} \mathrm{C}$. The highest ductility at strain rate $6,28 \mathrm{~s}^{-1}$ can be observed at temperature $1100{ }^{\circ} \mathrm{C}$. Increasement of strain rate to $25,2 \mathrm{~s}^{-1}$ 
doesn `t lead to change in ductile properties;

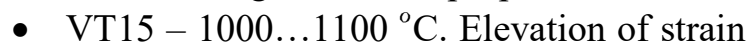

rate leads for constant increasement of ductility of this alloy;

- TS5 - 950 ..1100 ${ }^{\circ} \mathrm{C}$. This alloy shows almost insensible behavior on changing the strain rate in studied temperature range;

- TS6 - 1150 ..1200 ${ }^{\circ} \mathrm{C}$. Its ductile behavior is similar to VT15;

PT7-M $-1000 \ldots 1050{ }^{\circ} \mathrm{C}$. This alloy similarly to TS5 is not sensible to changing the strain rate in studied temperature range.

Estimation of flow stress. It is also known [11, 12] that modern high-efficiency technologies of metal forming require consideration of the properties of titanium alloys. This is because currently the rheological concept of plastic deformation is applied to process calculations. This concept is the basis for most finite-element programs for simulation of metal forming processes [13, 14]. These programs require input of the rheological properties of deformed material in form of a table or an equation. Such data is usually obtained experimentally under certain conditions, being as possible close to conditions of the deformation process [15 - 17].

One of the most used equations, describing the rheological properties of a material, in finiteelement programs is a model in which followed equation is used to calculate the flow stress of a material. $[12,18]$ :

$$
\sigma_{f}=A e^{a_{1} T} T^{a_{9}} \varepsilon^{a_{2}} e^{a_{4} / \varepsilon}(1+\varepsilon)^{a_{5} T} e^{a_{7} \varepsilon} \dot{\varepsilon}^{a_{3}} \dot{\varepsilon}^{a_{8} T}
$$

where $\sigma_{\mathrm{f}}$ - flow stress, $\varepsilon$ - equivalent strain; $\dot{\varepsilon}-$ strain rate, $T$ - temperature, $A, a_{1}, a_{2}, a_{3}, a_{4}, a_{5}, a_{7}$, $a_{8}, a_{9}$ - coefficients, obtained during material testing in appropriate conditions.

Presented below results of hot-torsion experiments and its statistical processing are aimed to determine the regression coefficients of equation (4) which can be applied to calculation of parameters of seamless tubes extrusion for studied titanium alloys. Due to strain-stress state inside the extrusion container and its outgoing zone the flow stress might be determined using the value of the shear stress:

$$
\sigma_{f}=\sqrt{3} \cdot \tau_{s}
$$

where $\tau_{s}$ - shear stress close outer surface of the test specimen under the torsion [19].

$$
\tau_{s}=\frac{12 \cdot \mathrm{M}_{\operatorname{Max}}}{\pi \cdot D^{3}}
$$

where $\mathrm{M}_{\text {Max }}-$ maximum torque, $\mathrm{N} \times \mathrm{m}$.

Statistical analysis of the data, performed on Fig. 3 , allow to determine the coefficients of equation (4) which are necessary for subsequent theoretical (using numerical modeling) studies. These coefficients are given in the Table 2. The range of recommended applicability of the coefficients indicated in Table 2 are shown in Table 3.

Practical application of obtained data could be more convenient when flow stress will be performed as a strain-stress dependence. Thus, using coefficients from the Table 2 we drew graphs of the flow stress depending on the logarithm of extrusion ratio $\ln \lambda$. These graphs were built considering the best ductile behavior range, which are shown above, both for lower and upper temperatures of that range. The strain rate were 1,10 and $20 \mathrm{~s}^{-1}$ what is widely used in hot tube extrusion.

Table 2. The coefficients for equation (4)

\begin{tabular}{|c|c|c|c|c|c|c|c|c|c|}
\hline Alloy grade & $A$ & $a_{1}$ & $a_{2}$ & $a_{3}$ & $a_{4}$ & $a_{5}$ & $a_{7}$ & $a_{8}$ & $a_{9}$ \\
\hline VT1-0 & $7.5 \mathrm{e}^{38}$ & 0.01 & 1.54 & 0.34 & 0.12 & -0.002 & 0.17 & -0.0002 & -14.03 \\
\hline VT14 & $8.4 \mathrm{e}^{8}$ & -0.01 & 3.26 & -2.72 & 0.3 & -0.005 & 0.3 & 0.002 & -0.41 \\
\hline VT15 & 9.72 & -0.002 & 0.27 & 1.67 & 0.02 & 0.0015 & -0.17 & -0.002 & 0.42 \\
\hline TS-5 & 0.032 & -0.015 & 0.09 & 0.29 & -0.08 & 0.0007 & -0.02 & -0.0004 & 3.23 \\
\hline TS-6 & 0.6 & -0.003 & 1.08 & 0.15 & 0.04 & -0.0002 & -0.1 & -0.0002 & 1.22 \\
\hline PT-7M & $4.5 \mathrm{e}^{39}$ & 0.01 & 1.22 & -0.7 & 0.03 & -0.003 & 0.32 & 0.0007 & -13.98 \\
\hline
\end{tabular}

Table 3. The interval of applicability of the coefficients from the Table 2 for equation (3)

\begin{tabular}{|c|c|c|c|c|}
\hline Alloy grade & Temperature $^{\circ} \mathrm{C}$ & Logarithm of the extrusion ratio, $\ln \lambda$ & Strain rate $\dot{\varepsilon}, s^{-1}$ & Figure \\
\hline VT1-0 & $800 \ldots 1200$ & $0.06 \ldots 8.85$ & $0.1 \ldots 20$ & $\mathrm{a}$ \\
\hline VT14 & $900 \ldots 1200$ & $0.06 \ldots 5.5$ & $0.1 \ldots 20$ & $\mathrm{~b}$ \\
\hline VT15 & $900 \ldots 1200$ & $0.06 \ldots 9.45$ & $0.1 \ldots 20$ & $\mathrm{c}$ \\
\hline TS-5 & $900 \ldots 1000$ & $0.06 \ldots 7.3$ & $0.1 \ldots 20$ & $\mathrm{~d}$ \\
\hline TS-6 & $1000 \ldots 1250$ & $0.06 \ldots 8.1$ & $0.1 \ldots 20$ & $\mathrm{e}$ \\
\hline PT-7M & $800 \ldots 1200$ & $0.06 \ldots 9.3$ & $0.1 \ldots 20$ & $\mathrm{f}$ \\
\hline
\end{tabular}


Development of the flow stress presented in the Fig. 4 varies for studied alloys. It's due to features of dynamical processes in structure, prescribed by the chemical composition. We didn't aim to study it deeply here. Nevertheless, we can recommend
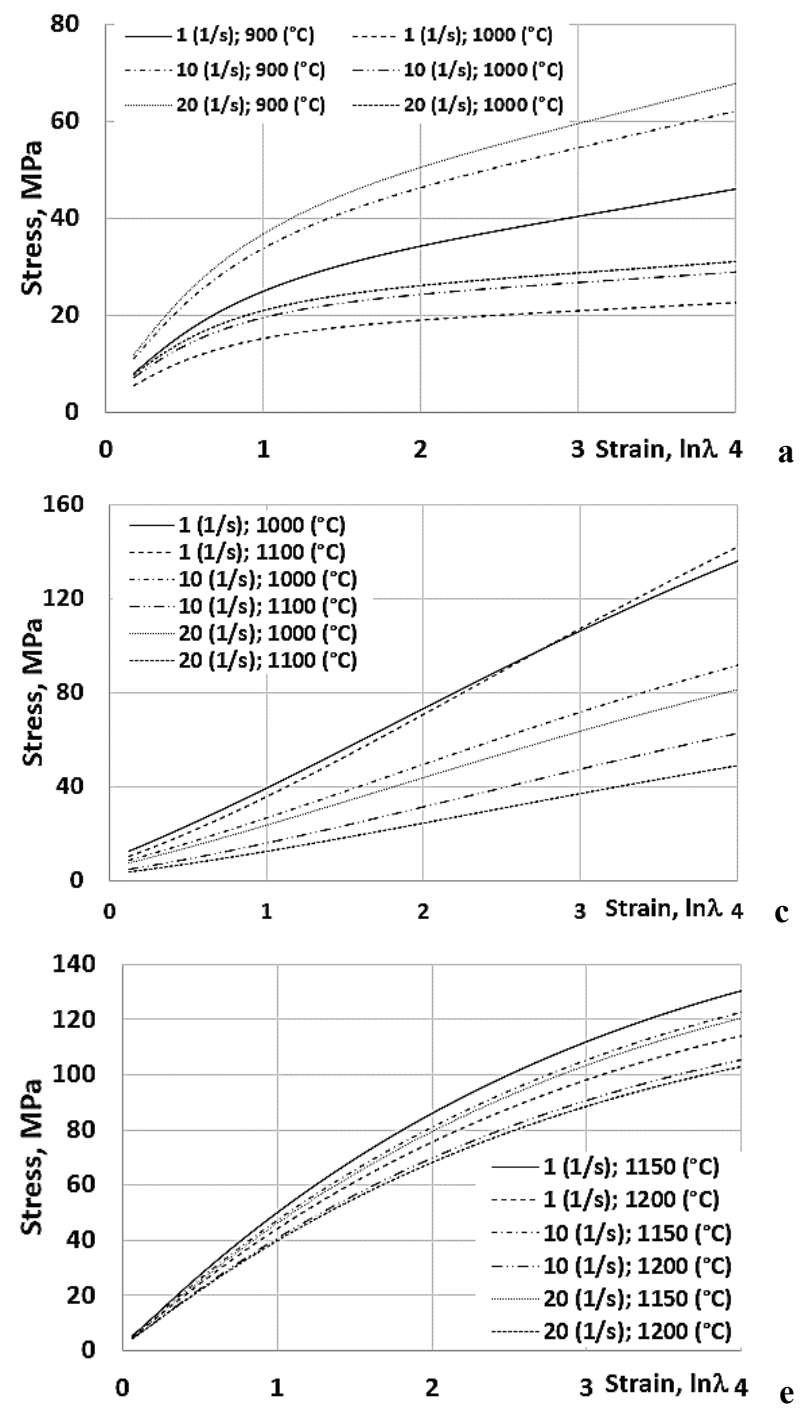

planning the technology staying between lower and upper curves. Work close to upper border causes an elevation of the load and temperature, lower area increases risk of internal failures and microcracks $[20,21]$.
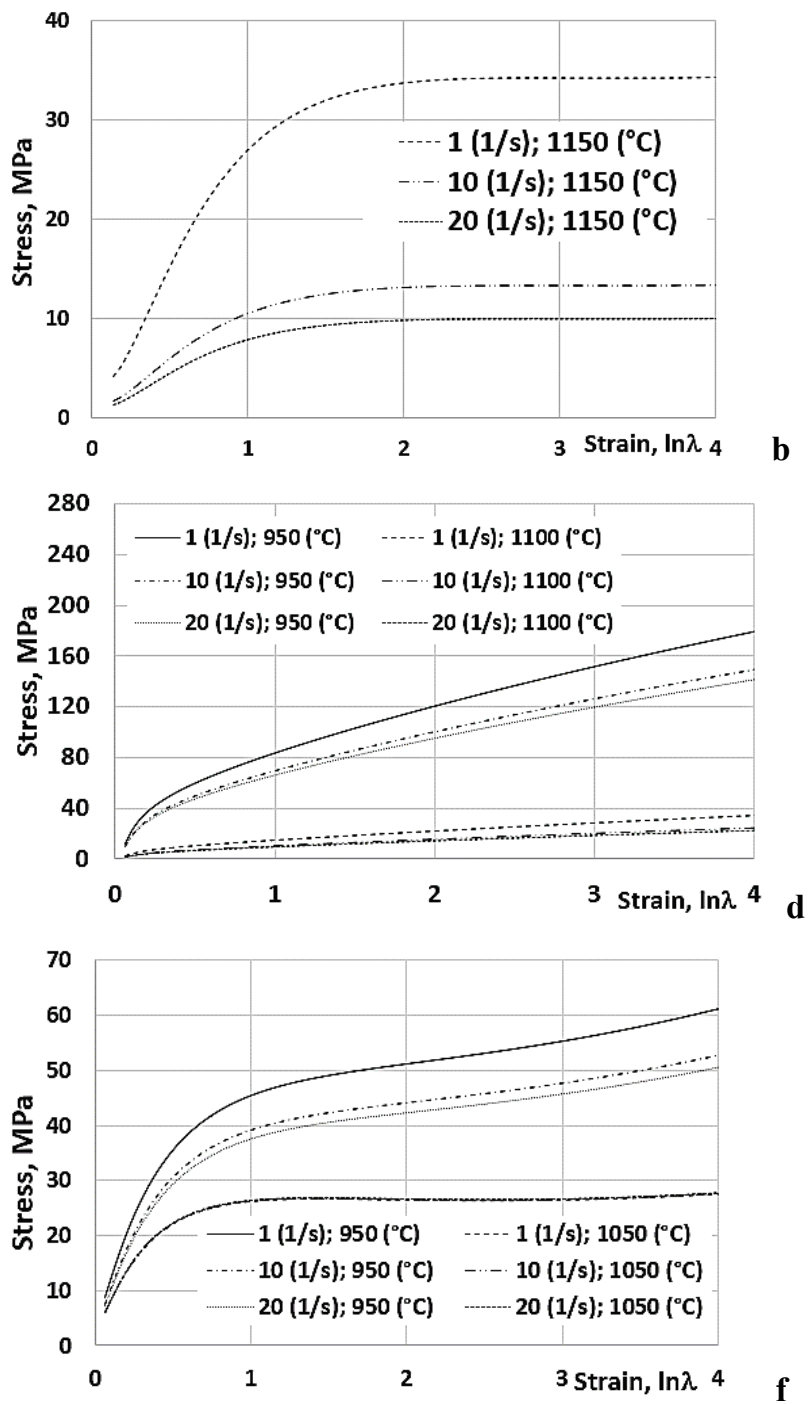

Fig. 4. Strain-stress dependences built using the coefficients from the table 2 according to the equation (4) for: a -VT1-0; b-VT14; c-VT15; d - TS5; e - TS6; f - PT7-M

Conclusions. 1. Based on results of hot tension tests the temperature range of metal forming with maximal duration of ductile behavior for studied was estimated for each of studied titanium alloy: VT1-0 - 900...1000 ${ }^{\circ} \mathrm{C}$; VT14 - 1050..1150 ${ }^{\circ} \mathrm{C}$; VT15 - $1000 \ldots 1100^{\circ} \mathrm{C}$; TS5 - 950..1100 ${ }^{\circ} \mathrm{C}$; TS6 - $1150 \ldots 1200{ }^{\circ} \mathrm{C}$; PT7-M - $1000 \ldots 1050{ }^{\circ} \mathrm{C}$.

2 . The sensibility to strain rate at hot deformation was studied. It was found that it falls at temperatures of maximal duration of ductile behavior for majority of studied titanium alloys, excepting VT15 and PT7-M.

3. Using the statistical analysis of the results of hot torsion tests coefficients for Hensel-Spittel equation for estimation of flow stress at hot deformation are found for studied titanium alloys. The range of recommended applicability of the coefficients is specified.

4. Flow curves of studied titanium alloys in temperature range of maximal duration of ductile behavior are built for widely used at tubes hot extrusion strain rate $\left(1 \ldots 20 \mathrm{~s}^{-1}\right)$.

5. Favorable ranges of "Strain - Strain rate Temperature" combination, applying to the hot tubes extrusion are recommended. 


\section{Referernces}

1. Danchenko, V. N., Frolov, Ia. V., Dekhtyarev, V. S., Golovchenko, A. P., Belikov, Yu. M., Tereshchenko, A. A., \& Chigirinskiy, Yu. V. (2011). Development of Pipe Cold Pilger Rolling Mode Computation Method with Account of Metal Properties Change. Metallurgical and mining industry, 3(3) 110-113.

2. Andreiev, A., Golovko, O., Frolov, Ia., Nurnberger, F., Wolf, La, Schaper, M., \& Grydin, O. (2015). Testing of pipe sections. Materials Testing, 57(7-8), 643-648. doi:10.3139/120.110759.

3. Hubkin, S. I. (1961). Plasticheskaiia deformatsiia metallov. Vol. 1-3. Moskva: Metallurgizdat.

4. Illarionov, A. G., \& Popov, A. A. (2014). Tehnologicheskie $i$ ekspluatatsionnie svoistva titanovyh splavov. Yekaterinburg: Ural. un-t.

5. Pernis, R., Bidulská, J., Kvačkaj, T., \& Pokorný, I. (2011). Application of the torsion test in calculating the extrusion force. Archives of metallurgy and materials, 56(1), 81-85. doi: 10.2478/v10172011-0009-9.

6. Kolmogorov, V. L. (1977). Plastichnost i razrushenie. Moskva: Metallurgiia.

7. Nadai, A. (1969). Plastichnost i razrushenie tverdyh tel. Moskva: Mir.

8. Splavy titanovye. Marki: OST 1.90013-81. Vzamen OCT 1 90013-78; vved. 1981-07-01.

9. Medvediev, M. I. (1974). Deformiruemost mettalov pri goriachem pressovanii trub: dis. kand.: 05.16.05. Dnepropetrovsk.

10. Yang, L.H., \& Wu, L.Z. (2011). Determination of hardening coefficient of large strain constitutive model based on torsion tests. Advanced materials research, 197-198, 1528-1531. doi: 10.4028/ www.scientific.net/AMR.197-198.1528.

11. Shlomchak, G. G. (2005). Reologicheskaia kontseptsiia $\mathrm{v}$ teorii prokatki metallov. Teoriia $i$ praktika metallurgii, (3), 39-43.

12. Spittel, T., \& Spittel, M. (2009). Ferrous Alloys. Vol. 2. New York: Springer.

13. Bouchard, P. O., Laurent, T., \& Tollier, L. (2008). Numerical modeling of self-pierce riveting From riveting process modeling down to structural analysis. Journal of Materials Processing Technology, 202(1-3), 290-300. doi: 10.1016/j.jmatprotec. 2007.08.077.

14. Chenot, J. L., \& Oñate, E. (Eds.). (1988). Modelling of Metal Forming Processes. doi: 10.1007/978-94-009-1411-7.

15. Xin Hou, Zhanqiang Liu, Bing Wang et al. (2018). Stress-Strain Curves and Modified Material Constitutive Model for Ti-6Al-4V over the Wide Ranges of Strain Rate and Temperature. Materials, 11(6). doi:10.3390/ma11060938.
16. Bogatov, A. A., \& Panov, E. I. (2013). Effect of Stress-strain State during Helical Rolling on Metal and Alloy Structure and Ductility. Metallurgist, 57(5-6), 434-441. doi: 10.1007/s11015-0139751-8.

17. Hryts, A., Dyia, H., Baior, T. et al. (2014). Analiz raspredeleniia deformatsii i napriazhenii $\mathrm{v}$ protsesse prokatki prutkov iz splava marniia AZ31 na trehvalkovom vintovom stane. Innovatsionnie tehnologii $v$ metallurgii i mashinostroenii : materialy mezhdunaridnoy molodezhnoy nauchnoprakticheskoy konferentsii (Yekaterinburg, 2630.11.2013). Yekaterinburg: Izdatelstvo Uralskogo universiteta, 338-341.

18. Henzel, A., \& Shpittel, T. (1982). Raschet energosilovyh parametrov $v$ protsessah obrabotki metallov davleniem. Moskva: Metallurgiia.

19. Medvediev, M.I., Guliaev, Yu.G., \& Chukmasov, S.A. (1986). Sovershenstvovanie protsessa pressovaniia trub. Moskva: Metallurgiia.

20. Golovko, A. N., Rodman, D., Nürnberger, F., Schaper, M., Frolov, Ia., \& Beliaiev, S. (2012). Investigation of the water-air cooling process of the thick- walled extruded profile made of alloy EN AW-6060 on the output table. Metallurgical and Mining Industry, 4, 66-74.

21. Lütjering. G., Williams. J. C., Gysler, A. (2000). Microstructure and Mechanical Properties of Titanium Alloys. Microstructure and Properties of Materials, 2, 1-77. doi: 10.1142/9789812793959_ 0001 .

\section{Бібліографічний список}

1. Development of Pipe Cold Pilger Rolling Mode Computation Method with Account of Metal Properties Change / V. N. Danchenko et al. Metallurgical and mining industry. 2011. Vol. 3, No. 3. P. $110-113$.

2. Testing of pipe sections / A. Andreiev et al. Materials Testing. 2015. Vol. 57, No. 7-8. P. 643648. DOI: $10.3139 / 120.110759$.

3. Губкин С. И. Пластическая деформация металлов : в 3 т. Москва : Металлургиздат. 1961.

4. Илларионов А. Г., Попов А. А. Технологические и эксплуатационные свойства титановых сплавов. Екатеринбург: Урал. ун-т, 2014. $137 \mathrm{c}$.

5. Pernis R., Bidulská J., Kvačkaj T., Pokorný I. Application of the torsion test in calculating the extrusion force. Archives of metallurgy and materials. 2011. Vol. 56 (1). P. 81-85. DOI: 10.2478/ v10172-011-0009-9.

6. Колмогоров В. Л. Пластичность и разрушение. Москва : Металлургия, 1977. 336 с. 
7. Надаи А. Пластичность и разрушение твердых тел. Москва : Мир, 1969. 863 с.

8. Сплавы титановые. Марки : ОСТ 1.9001381. Взамен ОСТ 1 90013-78 ; введ. 1981-07-01.

9. Медведев М. И. Деформируемость металлов при горячем прессовании труб : дис. канд. : 05.16.05. Днепропетровск, 1974. 194 с.

10. L.H. Yang, L.Z. Wu. Determination of hardening coefficient of large strain constitutive model based on torsion tests. Advanced materials research. - 2011. Vol. 197-198. P. 1528-1531.

11. Шломчак Г. Г. Реологическая концепция в теории прокатки металлов. Теория и практика металлургии. 2005. № 3(52). С. 39-43.

12. Thilo Spittel, Marlene Spittel. Ferrous Alloys. Vol. 2. New York : Springer, 2009. 800 p.

13. P. O. Bouchard, T. Laurent, L. Tollier. Numerical modeling of self-pierce riveting - From riveting process modeling down to structural analysis. Journal of Materials Processing Technology. 2008. No 202(1-3). P. 290-300. DOI: 10.1016/ j.jmatprotec.2007.08.077

14. Chenot, J. L., Oñate, E. (Eds.). Modelling of Metal Forming Processes. 1988. https://doi:10.1007/978-94-009-1411-7

15. Stress-Strain Curves and Modified Material Constitutive Model for Ti-6Al-4V over the Wide Ranges of Strain Rate and Temperature / Xin Hou, Zhanqiang Liu, et al. Materials. 2018. Vol. 11, Issue 6. DOI: https://doi.org/10.3390/ma11060938

16. A. A. Bogatov, E. I. Panov. Effect of Stress-strain State during Helical Rolling on Metal and Alloy Structure and Ductility. Metallurgist. 2013. Volume 57, Issue 5-6. P. 434-441. DOI: https://doi.org/10.1007/s11015-013-9751-8

17. Анализ распределения деформации и напряжений в процессе прокатки прутков из сплава магния AZ31 на трехвалковом винтовом стане / А. Грыц и др. Инновационные технологии в металлургии и машиностроении : материалы международной молодежной научнопрактической конференции, 26-30 ноября 2013 г., Екатеринбург. Екатеринбург : Уральский ун-т, 2014. С. 338-341.

18. Хензель А., Шпиттель Т. Расчет энергосиловых параметров в процессах обработки металлов давлением : справ. изд. Москва : Металлургия, $1982.360 \mathrm{c.}$

19. Медведев М. И., Гуляев Ю. Г., Чукмасов С. А. Совершенствование процесса прессования труб. Москва : Металлургия, 1986. 151 с.

20. Investigation of the water-air cooling process of the thick- walled extruded profile made of alloy EN AW-6060 on the output table / A. N.
Golovko et al. Metallurgical and Mining Industry.2012. No 4(2). P. 66-74.

21. G. Lütjering, J. C. Williams, A. Gysler. Microstructure and Mechanical Properties of Titanium Alloys. Microstructure and Properties of Materials. 2000. Vol. 2. P. 1-77. DOI: https://doi.org/10.1142/ 9789812793959_0001

Мета. Метою даної роботи є уточнення температурно-деформаційних режимів пресування труб з титанових сплавів (ВТ1-0, ПТ-7М, BT-14, BT-15, TC-5 і TC-6) i визначення коефіиієнтів регресії рівняння Хензеля-Шпіттеля шляхом дослідження пластичності та опору деформачії при гарячому крученні зразків.

Методика. Дослідження на кручення проводили на випробувальній машині для кручення $з$ електронним силовимірювачем горизонтального типу, з максимальним крутний моментом $100 \mathrm{H} \times_{\mathcal{M}}$, температурна. Максимальна температура зразків при випробуваннях становила $1250^{\circ} \mathrm{C}$. Активне захоплення випробувальної машини має плавне регулювання обертів від 5 до 200 об/хв. Застосовуючи зразки з різним співвідноченням радіусу зразка до довжини робочої частини отримували діапазон зміни швидкостей деформації від 0,25 до $20 \mathrm{c}^{-1}$.

Результати. Основними результатами дослідження слід вважати експериментально визначені криві залежності крутного моменту від кута закручування зразка на зміну опору деформаиії металу, щзо дозволило уточнити температурний інтервал максимальної пластичності при обробиі тиском для сплавів ВТ1-0; ВT14; ВТ15; ТС5; ТС6; ПТ7-М. На підставі отриманих даних щодо опору деформаиії статистично розраховано коефічієнти рівняння Хензеля-Шпіттеля, які можуть бути використані для кількісного визначення виникаючого напруження при чисельному моделюванні з використанням методу скінченних елементів.

Наукова новизна. Одержали подальший розвиток відомості щодо експериментально визначених закономірностей впливу температурно-деформачійних режимів кручення на зміну величини опору деформації, що характерно для умов гарячого пресування труб. Це дозволяс прогнозувати енергосилові параметри процесу деформаиії, а також обирати пресове устаткування та підвищити продуктивність пресової лінї.

Практична цінність. Дослідження на кручення дозволили визначити раціональні температуро-швидкісні параметри прочесу пресування труб з титанових сплавів BT1-0; BT14; BT15; 
ТС5; ТС6; ПТ7-М для потужностей украӥнських підпиємств.

Ключові слова: титан, деформація, кручення, момент кручення, температура, швидкість деформачіï, опір деформачії, пресування, труба.

Цель. Целью данной работы является уточнение температурно-деформационных режимов прессования труб из титановых сплавов (BT1-0, ПТ-7M, ПТ-14, ВТ-15, ТС-5 и ТС-6) и определение коэффициентов регрессии уравнения Хензель-Шпиттеля путем исследования пластичности и сопротивления деформации при горячем кручении образиов.

Методика. Исследования на кручение проводили на испытательной машине для кручения c электронным силоизмерителем горизонтального типа, с максимальным крутящим моментом 100 Н火. температурна я. Максимальная температура образиов при испьтаниях составляла $1250{ }^{\circ} \mathrm{C}$. Активный захват испытательной машины имеет плавную регулировку оборотов от 5 до 200 об/мин. Используя образиы с различным соотношением радиуса образиа к длине рабочей части получали диапазон изменения скоростей деформаиии от 0,25 до $20 \mathrm{c}^{-1}$.

Результаты. Основными результатами исследования следует считать экспериментально определенные кривые зависимости крутящего момента от угла закручивания образиа на изменение сопротивления деформации металла, что позволило уточнить температурный интервал максимальной пластичности при обработке давлением для сплавов BT1-0; ВT14; ВT15; TC5; TC6; ПТ7-М. На основании полученных данных по сопротивлению деформачии статистически рассчитаны коэффициенты уравнения ХензельШпиттеля, которые могут быть использовань для количественного определения возникающего напряжения при численном моделировании $c$ использованием метода конечных элементов.

Научная новизна. Получили дальнейтее развитие сведения о экспериментально определенных закономерностях влияния температурнодеформационных режимов кручения на изменение величины сопротивления деформачии, что характерно для условий горячего прессования труб. Это позволяет прогнозировать энергосиловые параметры проиесса деформации, а также выбирать прессовое оборудование и повысить производительность прессовой линии.

Практическая ценность. Исследования на кручение позволили определить рачиональные температурно-скоростные параметры прочесса прессования труб из титановых сплавов ВТ10; ВT14; ВT15; ТС5; ТС6; ПТ7-М для условий мощности украинских предприятий.

Ключевые слова: титан, деформация, кручение, момент кручения, температура, скорость деформации, сопротивление деформации, прессование, труба.

Рукопис надійшов 17.10.2019 